\title{
No Effect of Transfusion Transmitted Virus Viremia on the Distribution and Activation of Peripheral Lymphocytes in Hemodialyzed Patients
}

\author{
Bertalan Fodora Erzsébet Ladányia Magdolna Aleksza ${ }^{b}$ Mária Takácsc

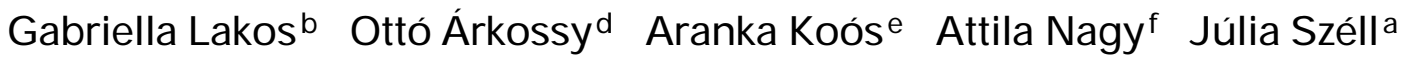 \\ Nora Klenka Enikő Sárváryg Sándor Sipka ${ }^{b}$ \\ aFMC Nephrology Center, Miskolc; ' 3 rd Department of Medicine, Center of Medicine and Health Sciences, \\ University of Debrecen; ' Department of Virology of the National Health Center, Budapest; \\ dMagyar-Med Dialysis Station, St Margaret Hospital, Budapest; eFMC Dialysis Station, Ózd; fFMC Dialysis Station, \\ Sátoraljaújhely; ${ }^{9}$ Semmelweis University, Department of Transplantation, Budapest, Hungary
}

\section{Key Words}

TTV $\cdot$ Lymphocytes $\cdot$ Cytokines $\cdot$ Hemodialysis

\begin{abstract}
Aim: We aimed to examine the distribution and activation of peripheral T cells in TTV positive $(n=32)$ and negative $(n=17)$ hemodialyzed patients. The control group $(n=20)$ consisted of healthy blood donors. Method: TTVDNA was detected by seminested PCR. CD3, CD4, CD8, CD19, CD56, CD3/HLA-DR, CD3/CD69 and the Th1/Th2 ratio of $T$ cells were analyzed by flow cytometry. Circulating IFN- $\gamma$, IL-2, IL-4, IL-6, IL-10, IL-13, TNF- $\alpha$, TGF- $\beta$ levels were measured by ELISA in the sera. Results: There was no difference between the CD3, CD4, CD8 and CD19 values of HD subjects. In addition, the expression of both activation markers, HLA-DR and CD69, was significantly elevated in the TTV-positive and -negative HD groups compared to the controls, but not showing any difference from each other. The measurements of intracellular cytokines showed the enhanced occurrence of INF- $\gamma+$ CD4 T cells, and decreased appearance of IL-4 +CD4 lym-
\end{abstract}

phocytes in the HD groups without any significant difference between the TTV virus positive and negative patients. In addition, HD also elevated the expression of IL10 in CD4 and CD8 (Th2) cells. There were only two significant changes in the levels of circulating cytokines: (a) IL-2 increased; (b) IL-13 decreased in both groups of HD patients compared to the controls, independently of TTV positvity or negativity. Conclusions: We assume that transfusion-transmitted virus does not cause any specific change in the distribution and activation of lymphocytes in the peripheral blood of hemodialyzed patients. Hemodialysis itself, however, results in a significant activation of peripheral $\mathrm{T}$ cells with the domination of increased production of Th1 type cytokines, IFN- $\gamma$, IL-2, in contrast to the decreased synthesis of Th2 type cytokines, IL-4 and IL-13. Furthermore, the increased expression of IL-10 in the CD4 and CD8 cells of HD patients can be the sign of a contraregulatory Th2 activation as an answer on the Th1 effect.

Copyright @2002 S. Karger AG, Basel

\begin{tabular}{ll}
\hline KARGER & ( ) 2002 S. Karger AG, Basel \\
Fax +41 61306 12 34 & \\
$\begin{array}{l}\text { E-Mail karger@karger.ch } \\
\text { www.karger.com }\end{array}$ & $\begin{array}{l}\text { Accessible online at: } \\
\text { www.karger.com/journals/nef }\end{array}$
\end{tabular}

Bertalan Fodor, BSc MSc

FMC Nephrology Center, Miskolc

Clinical Diagnostic Laboratory

Szentpéteri kapu 76, Miskolc 3501 (Hungary)

Tel./Fax +36 46501 470/501 475, E-Mail fodorb@fresenius.hu 


\section{Introduction}

In 1997, a novel human DNA virus was analyzed by Japanese researchers from the serum of a patient with posttransfusion hepatitis of unknown etiology $[1,2]$. The newly described virus was named TT after the initials of the patient. TTV is a single-stranded circular DNA virus [3-9]. The virus-specific IgM is detectable only for a short period of time, while IgG may be detectable for as long as 4 years. The channel of virus-transmission has proved to be both parenteral and enteral [10]. Some patients are able to eliminate the virus and others are not, resulting in the persistence of the virus infection over years. Many investigators reported the prevalence of the TTV infection to be around $1.5 \%$ in the healthy population. The frequency of the virus is higher in polytransfused patients; some authors even suggest a rate higher than $40 \%$ [11]. Hemodialyzed patients constitute a major group among those with history of frequent blood transfusions, with a higher risk to acquire TTV. Despite having detailed information about the structure, transmission routes, and epidemiology, the pathogenic importance of this virus is still unknown $[6,12]$.

In this study, we compared the distribution and activation of the peripheral lymphocytes as well as the levels of circulating and intracellular cytokines in TTV positive and TTV negative hemodialyzed (HD) patients and healthy controls.

\section{Patients and Method}

The study group comprised 49 patients undergoing hemodialysis program (TTV positive $n=32$, TTV negative $n=17$ ). For the clinical laboratory examinations we used uncitrated blood stored at $-20^{\circ} \mathrm{C}$ after centrifugation. Blood samples were collected in standard sterile vacuum tubes (BD Vacutainer tube) with sodium heparin to identify cell surface $\mathrm{CD}$ markers and intracytoplasmatic cytokines.

Detection of TTV was carried out by two-step semi-nested PCR technology $[6,13]$. The cell-surface $C D$ antigens were detected by a direct immunfluorescence method using monoclonal antibodies. For the evaluation of cell-surface markers and intracytoplasmatic cytokines we used Coulter EPICS XL-4 flow cytometer. Soluble cytokine levels were detected with Pharmingen OptEIA ELISA sets in the sera.

\section{Statistical Analysis}

Normality analysis of data distribution was performed by Kolmogorov-Smirnov's test. Significance analysis was carried out using Student's paired t test in the case of normal Gaussian distribution, while Mann-Whitney's test was used for the abnormal distribution. Any difference was considered significant if $\mathrm{p}$ was $<0.05$.

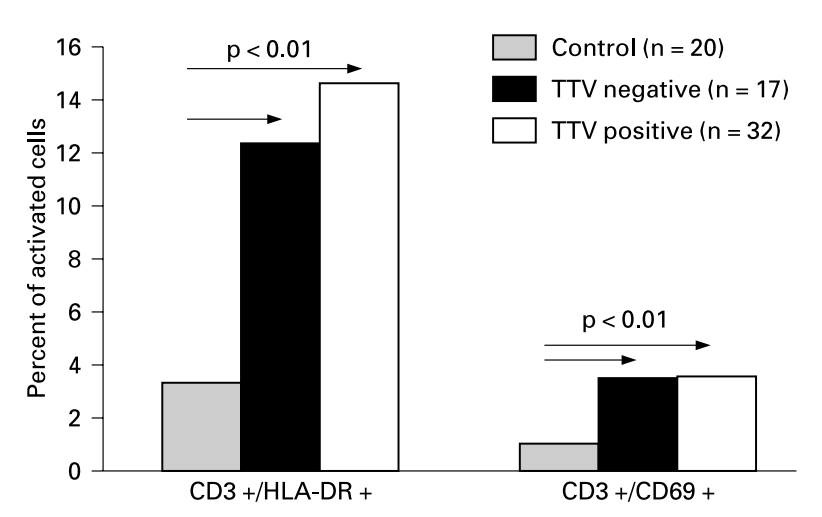

Fig. 1. Occurrence of HLA-DR and CD69 activation markers.

\section{Results}

Distribution of CD3, CD3/HLA-DR, CD3/CD69, CD4, CD8, CD19 and CD56 Positive Lymphocytes in the TTV Positive and Negative Hemodialyzed Patients and Healthy Controls

The percent of CD56 cells was significantly higher both in the TTV negative and TTV positive groups of HD patients compared to the healthy controls (16.12 and 17.41 vs. $9.75 \%, \mathrm{p}<0.01 ; \mathrm{p}<0.01)$. The difference between the values of two HD groups (16.12 vs. 17.41\%) was not significant. Both in the TTV negative and TTV positive HD patients, the occurrence (percent) of HLADR activation marker significantly increased compared to the controls (12.26 and 14.56 vs. $3.28 \%$ p $<0.01 ; p<$ 0.01 ), but without any significant difference between them. The same tendency could be observed concerning the values of CD69 positive cells, too. Percent of CD69 positivity was 3.43 vs. $0.9 \%(\mathrm{p}<0.01)$ in the TTV negative, and 3.46 vs. $0.9 \%(\mathrm{p}<0.01)$ in the TTV-positive patients. There was no significant difference between the values of the two HD groups (3.43 vs. 3.46\%) (fig. 1).

\section{Expression of Intracellular INF- $\gamma, I L-4, I L 10$ in the \\ CD4 and CD8 Lymphocytes of TTV-Positive and \\ -Negative Hemodialyzed Patients and Healthy \\ Controls}

In both groups of HD patients the expression (percent) of IFN- $\gamma+$ CD4 cells increased but the elevation was statistically significant only in the TTV-positive subjects (TTV-positive patients: 29.85 vs. $22.06 \%$ p $<0.01$, TTVnegative patients: 25.72 vs. $22.06 \% \mathrm{p}=$ not significant). On the other hand, the percent of IL- $4+$ CD4 cells 
Table 1. Expression of intracellular cytokines

\begin{tabular}{lccclcr}
\hline & $\begin{array}{l}\text { IFN- } \gamma / \mathrm{CD} 4 \\
\%\end{array}$ & $\begin{array}{l}\text { IL-4/CD4 } \\
\%\end{array}$ & $\begin{array}{l}\text { IFN- } \gamma / \mathrm{CD} 8 \\
\%\end{array}$ & \multicolumn{1}{l}{$\begin{array}{l}\text { IL-4/CD8 } \\
\%\end{array}$} & $\begin{array}{l}\text { IL-10/CD4 } \\
\%\end{array}$ & $\begin{array}{l}\text { IL-10/CD8 } \\
\%\end{array}$ \\
\hline Control $(\mathrm{n}=20)$ & $22.6 \pm 6.25$ & $1.12 \pm 0.72$ & $43.4 \pm 8.45$ & $0.59 \pm 0.72$ & $2.85 \pm 4.1$ \\
TTV-negative $(\mathrm{n}=17)$ & $25.72 \pm 13.8$ & $0.17 \pm 0.15$ & $40.47 \pm 12.55$ & $0.91 \pm 1.29$ & $7.29 \pm 8.23$ & $3.7 \pm 4.26$ \\
TTV-positive $(\mathrm{n}=32)$ & $29.85 \pm 10.38$ & $0.28 \pm 0.29$ & $39.29 \pm 13.03$ & $0.72 \pm 0.9$ & $7.98 \pm 9.94$ & $6.43 \pm 6.29$ \\
p1 & n.s. & $<0.01$ & n.s. & n.s. & 0.04 & 0.02 \\
p2 & $<0.01$ & $<0.01$ & n.s. & n.s. & 0.03 & n.s. \\
p3 & n.s. & n.s. & n.s. & n.s. & n.s. \\
\hline
\end{tabular}

p1 = Control vs. TTV-negative; $\mathrm{p} 2$ = control vs. TTV-positive; $\mathrm{p} 3$ = TTV-positive vs. TTV-negative.

Table 2. Levels of circulating cytokines

\begin{tabular}{|c|c|c|c|c|c|c|c|c|}
\hline & $\begin{array}{l}\text { IFN- } \gamma \\
\mathrm{pg} / \mathrm{ml}\end{array}$ & $\begin{array}{l}\text { IL-2 } \\
\mathrm{pg} / \mathrm{ml}\end{array}$ & $\begin{array}{l}\text { IL-4 } \\
\mathrm{pg} / \mathrm{ml}\end{array}$ & $\begin{array}{l}\text { IL-10 } \\
\mathrm{pg} / \mathrm{ml}\end{array}$ & $\begin{array}{l}\text { IL-13 } \\
\mathrm{pg} / \mathrm{ml}\end{array}$ & $\begin{array}{l}\text { TGF- } \beta \\
\mathrm{ng} / \mathrm{ml}\end{array}$ & $\begin{array}{l}\text { TNF- } \alpha \\
\text { pg/ml }\end{array}$ & $\begin{array}{l}\text { IL-6 } \\
\mathrm{pg} / \mathrm{ml}\end{array}$ \\
\hline Control $(n=20)$ & $13.05 \pm 14.78$ & $3.81 \pm 5.89$ & $3.32 \pm 5.08$ & $5.64 \pm 4.09$ & $0.84 \pm 0.79$ & $1.04 \pm 1.78$ & $1.29 \pm 2.15$ & $0.56 \pm 0.63$ \\
\hline TTV-negative $(\mathrm{n}=17)$ & $17.27 \pm 14.26$ & $18.41 \pm 23.2$ & $15.73 \pm 20.33$ & $4.8 \pm 6.35$ & $0.12 \pm 0.16$ & $0.96 \pm 2.2$ & $1.47 \pm 1.53$ & $1.9 \pm 4.2$ \\
\hline TTV-positive $(\mathrm{n}=32)$ & $15.61 \pm 22.86$ & $15.02 \pm 18.28$ & $6.45 \pm 11.91$ & $9.62 \pm 13.31$ & $0.07 \pm 0.14$ & $1.76 \pm 5.13$ & $0.7 \pm 1.15$ & $12.58 \pm 42.53$ \\
\hline p1 & n.s. & $\mathrm{p}<0.01$ & n.s. & n.s. & $\mathrm{p}<0.01$ & n.s. & n.s. & n.s. \\
\hline $\mathrm{p} 2$ & n.s. & $\mathrm{p}<0.01$ & n.s. & n.s. & $\mathrm{p}<0.01$ & n.s. & n.s. & n.s. \\
\hline p3 & n.s. & n.s. & n.s. & n.s. & n.s. & n.s. & n.s. & n.s. \\
\hline
\end{tabular}

decreased significantly in both groups compared to the controls (TTV-positive patients: 0.28 vs. $1.12 \% \mathrm{p}<0.01$, TTV-negative patients: 0.17 vs. $1.12 \% \mathrm{p}<0.01)$. The expressions of neither IFN- $\gamma$ nor IL-4 were different in CD8 cells. In addition, IL-10 was expressed at a higher extent both in CD4 and CD8 lymphocytes of TTV-positive and -negative groups of HD patients (CD4: 7.98 and 7.29 vs. $2.85 \% \mathrm{p}=0.04 ; \mathrm{p}=0.03$; CD8: 6.43 and 9.50 vs. 3.7 , n.s. $\% \mathrm{p}=0.02$ ). (These data are shown in table 2.) According to these data, HD resulted in dual effects on the regulation of $\mathrm{Th} 1$ and $\mathrm{Th} 2$ responses. Once it increased the expression of IFN- $\gamma$, on the other hand, it decreased the expression of IL-4 in the CD4 cells (Th1 influence). Second, HD increased the expression of IL-10 both in CD4 and CD8 cells (Th2 effect) (table 1).

Changes in the Levels of Circulating Cytokines in the Sera of TTV-Positive and-Negative Hemodialyzed Patients and Healthy Controls

The levels of circulating IL-2 significantly increased in the sera of both groups of hemodialyzed patients compared to the controls (TTV-positive subjects: 15.02 vs.
$3.81 \mathrm{pg} / \mathrm{ml}, \mathrm{p}<0.01$, TTV-negative subjects: $18.41 \mathrm{vs}$. $3.81 \mathrm{pg} / \mathrm{ml}, \mathrm{p}<0.01)$. On the other hand, the levels of IL-13 significantly decreased (TTV-positive patients: 0.07 vs. $0.84 \mathrm{pg} / \mathrm{ml}, \mathrm{p}<0.01$, TTV-negative patients: 0.12 vs. $0.84 \mathrm{pg} / \mathrm{ml}, \mathrm{p}<0.01)$. There were no differences in the levels of IFN- $\gamma$, IL-4, IL-10, TGF- $\beta$, TNF- $\alpha$ and IL-6 (table 2).

\section{Discussion}

Patients undergoing hemodialysis belong to a group of higher risk of hepatotropic virus infections. Some viruses, particularly the $\mathrm{HCV}$, can modulate the systemic immunoregulation beside its local effects [15-21]. Though several reports were published on TTV [1-13], the pathogenic importance of this virus remained still unknown. For this reason, we aimed at investigating the influence of TTV positivity on some parameters of the immunoregulation in HD patients.

There were no significant differences in the age, number of transfusions and the serum levels of AST, ALT, 
GGT, ALP and bilirubin in the TTV-positive and -negative HD patients and the normal controls included for this study.

According to our data, all the other measurements on the components of immune system did not show any TTV specific alteration induced by the virus $(\mathrm{CD}$ markers, expression of activation markers: HLA-DR and CD69, the expression of intracytoplasmic cytokines: IFN- $\gamma$, IL-4, IL-10, the levels of circulating cytokines: IFN- $\gamma$, IL-2, IL4, IL-13, TGF- $\beta$, TNF- $\alpha$, IL-6.

On the other hand, we could observe some new HD specific changes. The increased production of proinflammatory cytokines as IL-1 and TNF- $\alpha$ [22-27], furthermore, the significant elevation of the rate of CD14+CD16+ monocytes were described earlier already [28]. However, the HD related novelties are in our observations that HD: (a) increases the ratio of CD56 NK cells in the periphery; (b) elevates the HLA-DR and CD69 activation markers in CD3 cells; (c) has dual effects on the expression of Th1 and Th2 types of intracytoplasmic cytokines, i.e. increases the expression of IFN- $\gamma$ and decreases IL-4 in CD4 cells (Th1 effect); furthermore, HD raises the expression IL-10 in CD4 and CD8 cells (Th2 effect), and (d) elevates the circulating level of IL-2 and diminishes that of IL-13 (Th1 effect). These changes are in a good accordance to those findings that the Th1 and Th2 polarization is not a rigid state in the immune system. The actual dominance of one of them involves a counterregulatory activation of the other part [29]. That can be the case also in the presented phenomenon.

In addition, our data were analyzed also from the aspect of $\mathrm{HCV}$ positivity of the patients because $\mathrm{HCV}$ became known as a strong modifier of the immune system. The number of $\mathrm{HCV}$-positive patients was 13 among the 32 TTV-positive patients. All the TTV-negative subjects were free of $\mathrm{HCV}$ infections, too; they represented a 'pure' group, influenced only by HD. Therefore, we tested also another group of HD patients who were HCV positive (verified by PCR), but they were without TTV infection $(\mathrm{n}=9)$. In TTV and HCV double-positive HD patients, where the coincidence of all the three potential cell-activating factors existed (HD, HCV, TTV), the expression of IFN- $\gamma+$ in CD4 cells was significantly higher than in the normal controls ( 31.92 vs. $22.34 \%, \mathrm{p}<0.01)$. However, there was no significant difference in the values of HCV-positive vs. HD, the TTV-positive vs. HD and the TTV-negative vs. HD patients compared to each other and to the normal controls (these data are not presented). This fact does not alter the conclusion that TTV positivity is without any virus-specific influence on the activation markers of $\mathrm{T}$ cells, on the Th1 and $\mathrm{T} 2$ polarization and cytokine production of $\mathrm{T}$ cells in HD patients. It has to be mentioned, however, that the combined virus infection, TTV and HCV positivity, can already result in a significant change in the T-cell response (e.g. the increased expression of IFN- $\gamma$ in CD4 cells).

\section{Acknowledgements}

We must express our gratitude to the FMC Dialysis Center Ltd. for their sponsorship of this study. This work was supported by grant T034470 of Hungarian. Scientific Research Fund (OTKA).

\section{References}

1 Nishizawa T, Okamoto H, Konishi K, Yoshizawa H, Miyakawa Y, Mayumi M: A novel DNA virus (TTV) associated with elevated transaminase levels in posttransfusion hepatitis of unknown etiology. Biochem Biophys Res Commun 1997;241:92-97.

2 Okamoto H, Nishizawa T, Kato N, Ukita M, Izuka $\mathrm{H}$ : Molecular cloning and characterization of a novel DNA virus (TTV) associated with posttransfusion hepatitis of unknown etiology. Hepatol Res 1998;10:1-16.

3 Okamoto H, Nishizawa T, Ukita M: A novel unenveloped DNA virus (TT virus) associated with acute and chronic non $A$ to $G$ hepatitis. Intervirology 1999;42:196-204.
4 Charlton M, Adjei P, Poterucha J, Zein N, Moore B, Therneau T: TT-virus infection in North America blood donors, patients with fulminant hepatic failure, and cryptogenic cirrhosis. Hepatology 1998;28:839-842.

5 Simmonds P, Davidson F, Lycett C, Prescott LE, Macdonald DM, Ellender J, Yap PL, Ludlam CA, Haydon GH, Gillon J, Jarvis LM: Detection of a novel DNA virus (TTV) in blood donors and blood products. Lancet 1998; 352:191.

6 Naumov NV, Petrova EP, Thomas MG, Williams R: Prescence of a newly described human DNA virus (TTV) in patients with liver disease. Lancet 1998;352:195-197.

7 Prescott LE, Simmonds P: Global distribution of transfusion-transmitted virus (letter). N Eng J Med 1998;339:776-777.
8 Tanaka $\mathrm{H}$, Okamoto $\mathrm{H}$, Luengrojanakul $\mathrm{P}$, Chainuvati $\mathrm{T}$, Tsuda F, Tanaka T: Infection with an unenveloped DNA virus (TTV) associated with posttransfusion non-A to $G$ hepatitis in hepatitis patients and healthy blood donors in Thailand. J Med Virol 1998;56:234-238.

9 Tanaka H, Mizokami M, Orito E, Nakano T, Kato T Ding X: A new genotype of TT virus (TTV) infection among Colombian native Indians. J Med Virol 1999;57:264-268.

10 Okamoto H, Akahane Y, Ukita M, Fukuda M, Tsuda F, Miyakawa Y: Fecal excretion of a non enveloped DNA virus (TTV) associated with posttransfusion non-A-G hepatitis. J Med Virol 1998;56:128-132. 
11 Shibuya A, Satomichi A, Takeuchi A, Saigenji K, Sakurai K, Kobayashi N, Yoshida A: Transfusion transmitted virus infection in patients on maintenance haemodialysis and in hospital workers. J Hosp Infect 2001;47:277-281.

12 Sugiyama K, Goto K, Ando T, Mizutani F, Terabe K, Kawabe Y: Prevalence of TTV DNA among children with a history of transfusion or liver disease. J Med Virol 2000;60:172-176.

13 Sambrook J, Fritsch EF, Maniatis T: Molecular Cloning: A Laboratory Manual., Cold Spring Harbor, Cold Spring Harbor Laboratory, 1989.

14 Pereira BJ, Levey AS: Hepatiits C virus infection in dialysis and renal transplantation. Kidney Int 1997;51:981-999.

15 Sarih M, Bouchrit N, Benslimane A: Different cytokine profiles of peripherial blood mononuclear cells from patients with persistent and self-limited hepatitis $C$ virus infection. Immun Lett 2000;74:117-120.

16 Nagasaka A, Takahashi T, Sasaki T, Takimoto K, Miyashita K, Nakamura M, Wakahama O, Nishikawa S, Higuchi A: Cryoglobulinemia in Japanese patients with chronic hepatitis C virus infection: Host genetic and virological study. J Med Virol 2001;65:52-57.

17 Dalekos GN, Zachou K, Liaskos C: The antiphospholipid syndrome and infection. Curr Rheumatol Rep 2001;3:277-285.
18 Lunel F, Musset L: Mixed cryoglobulinemia and hepatitis $\mathrm{C}$ virus infection. Minerva Med 2001;92:35-42.

19 Lamprecht P, Moosig F, Gause A, Herlyn K, Csernok E, Hansen H, Gross WL: Immunological and clinical follow up of hepatitis $\mathrm{C}$ virus associated cryoglobulinaemic vasculitis. Ann Rheum Dis 2001;60:385-390.

20 Neuman MG, Benhamou JP, Malkiewicz IM, Akremi R, Shear NH, Asselah T, Ibrahim A, Boyer N, Martinot-Peignoux M, JacobsonBrown P, Katz GG, Le Breton V, Le Guludec G, Suneja A, Marcellin P: Cytokines as predictors for sustained response and as markers for immunomodulation in patients with chronic hepatitis C. Clin Biochem 2001;34:173-182.

21 Pyrsopoulos NT, Reddy K: Extrahepatic manifestations of chronic viral hepatitis. Curr Gastroenterol Rep 2001;3:71-78.

22 Descamps-Latscha B, Herbelin A, Nguyen AT, Roux Lambard P, Zingraff J, Moynot A, Verger C, Dahmane D, de Groete D, Jungers P: Balance between IL-1-beta, TNF-alpha and their specific inhibitors in chronic renal failure and maintenance dialysis: Relationships with activation markers of T-cells, B-cells and monocytes. J Immunol 1995; 154:882-892.

23 Takahashi C, Warrak EA, Ruzany F: Infectious endocarditis in patients on periodic hemodialysis. AMB Rev Assoc Med Bras 1991;37:119126.
24 Chatenoud L, Jungers P, Descamps-Latscha B: Immunological consideration of the uremic and dialyzed patient. Kidney Int 1994; 45(suppl 44):592-596.

25 Coles GA: Immunoglobulin and Complement. Contrib Nephrol. Basel, Karger, 1990, vol 85, pp 24-29.

26 Descamps-Latscha B, Herbelin A, Nguyen AT, Jungers P, Chatenaud L: Dysregulation du systeme immunitaire chez 1 uremique chronique et le dialyse. Press Méd 1995;24:405-410.

27 Pereira BJ, Shapiro L, King AJ, Falages ME, Strom JA, Dinarello CA: Plasma levels of IL$1 \beta$, TNF $\alpha$ and their specific inhibitors in undialyzed chronic renal failure, CAPD and hemodialysis patients. Kidney Int. 1994;45: 890-896.

28 Kawanaka N, Nagake Y, Yamamura M, Makino $\mathrm{H}$ : Expression of $\mathrm{Fc}$ gamma receptor III (CD16) on monocytes during hemodialysis in patients with chronic renal failure. Nephron 2002;90:64-71.

29 Wensky A, Marcondes MCG, Lafaille J: The role of IFN- $\gamma$ in the production of Th2 subpopulations: Implications for variable Th2-mediated pathologies in autoimmunity. J Immunol 2001;167:3074-3081. 